\title{
O RECALQUE E A CASTRAÇÃO NA HiSTERIA DE ANGÚSTIA: O PEQUeno Hans E Christoph HaitzManN
}

\author{
Ricardo Lincoln Laranjeira Barrocas $\star$ \\ Maria Luciana Silva Fernandes Félix $\star \star$
}

\begin{abstract}
Resumo
Consideramos uma pista lógica encontrada em Freud que atribuiu à histeria de angústia dois efeitos singulares. O primeiro é referente à fobia do pequeno Hans em que a libido é posta na forma de ansiedade. No segundo, a histeria de angústia pode combinar-se, em qualquer proporção, com a histeria de conversão. Supomos que tal fato tenha ocorrido com Christoph Haitzmann. As duas situações comparadas à heterossexualidade típica, em que o recalque e a castração são mais bem estruturados, mostram Hans ter concernido a uma homossexualidade atípica e Haitzmann a uma heterossexualidade atípica.
\end{abstract}

Palavras-chave: fobia; histeria de angústia; histeria masculina; homossexualidade atípica; psicanálise.

\section{REPRESSION AND CASTRATION IN ANXIETY HYSTERIA: LitTle Hans and Christopher HaitzmanN}

\begin{abstract}
One considers here a logical clue found in Freud who distinguishes two particular effects in anxiety hysteria. The first one is related to little Hans phobia where libido is transformed into anxiety only. In the second effect the anxiety hysteria grows, at any proportion, to a blending with the conversion hysteria. One supposes this has occurred to Christopher Haitzmann. These two cases were compared to the situation of typical heterosexuality where repression and castration are better structured. Some results are inferred: Hans regards to an atypical homosexuality and Haitzmann to an atypical heterosexuality.
\end{abstract}

Keywords: phobia; anxiety hysteria; masculine hysteria; atypical homosexuality; psychoanalysis.

\footnotetext{
^ Doutor em Psicologia pela Université Paris XIII. Professor Associado II do Departamento de Psicologia da Universidade Federal do Ceará. Coordenador do Círculo de Pesquisas sobre Lógica e Epistemologia das Psicologias da Universidade Federal do Ceará - CPLEP-UFC. Endereço: Universidade Federal do Ceará, Centro de Humanidades, Departamento de Psicologia. Avenida da Universidade, 2762. Benfica. Fortaleza, CE - Brasil. CEP: 60020-180.

E-mail: rbarrocas@uol.com.br

$\star \star$ Mestranda em Psicologia pela Universidade Federal do Ceará; Membro do Círculo de Pesquisas sobre Lógica e Epistemologia das Psicologias - CPLEP-UFC.

E-mail: lusfelix@bol.com.br
} 


\section{INTRODUÇÃO}

Que relações, quanto ao recalque e à castração no complexo de Édipo, podem-se encontrar em dois casos comentados por Freud: a fobia do pequeno Hans e a neurose demoníaca de Christoph Haitzmann? ${ }^{1}$ Segundo Freud, tratava-se, em Hans, de uma histeria de angústia que se desenvolvera "mais e mais para uma 'fobia"'. Quanto ao tratamento de casos semelhantes a este, Freud (1976[1909], p. 123) acrescentou: "no final, o paciente pode ter-se livrado de toda a sua ansiedade, ${ }^{2}$ mas somente ao preço de sujeitar-se a todos os tipos de inibições e restrições". O que dizer sobre Haitzmann? Na Introdução de Uma neurose demoníaca do século XVII, citando Charcot, Freud (1976[1922-1923]) correlacionou os fenômenos da possessão e do êxtase à histeria. Isso tem a ver também com o que foi inferido sobre os sintomas de Haitzmann. Freud (1976[1922-1923)], p. 98) os descreveu como: "visões, e 'absences', ${ }^{3}$ [em que ele] via e experimentava todo tipo de coisas, em acessos convulsivos acompanhados das sensações mais penosas; [...] paralisia das pernas e assim por diante".

De acordo com Freud, para as fobias como esta do pequeno Hans e que são as mais comuns, "o nome histeria de angústia" não pareceu impróprio. Para ele há uma semelhança completa entre a estrutura psicológica dessas fobias e a da histeria, "exceto em [...] único ponto. [A libido que foi] libertada do material patogênico pela repressão, ${ }^{4}$ não é convertida [isto é, desviada da esfera mental para uma inervação somática. Ela] é posta em liberdade na forma de ansiedade" (FREUD, 1976[1909], p. 123). No mesmo parágrafo, Freud acrescenta, todavia:

Nos casos clínicos com os quais nos defrontamos essa "histeria de angústia", pode estar combinada em alguma proporção com a histeria de conversão. Existem casos de pura histeria de conversão sem nenhum traço de ansiedade, assim como há casos de simples histeria de angústia que exibem sentimentos de ansiedade e de fobias, mas não têm mistura de conversão. O caso do pequeno Hans é da última espécie (FREUD, 1976[1909], p. 123).

Uma vez que, na tradução brasileira que acabamos de citar, foi omitido um termo relativo à distinção a que Freud procedeu, permitimo-nos fazer uma explicação. ${ }^{5} \mathrm{O}$ texto original é este: "In den vorkommenden Krankheitsfällen ${ }^{6}$ kann sich die 'Angsthysterie' mit der Konversionhysterie in beliebigem Ausmaße vermengen" (FREUD, 1969[1909], p. 99): "Nos casos de doença que (nos) aparecem, a histeria de angústia pode misturar-se em qualquer proporção com a histeria de conversão" (tradução nossa). Como desenvolvido anteriormente (BARROCAS, 2002), consideramos que Freud opôs duas situações quanto à histeria de angústia: a fobia de Hans e outra mais grave para a qual teria avançado uma situação inicial. Tratar-se-ia, nesta última, do que supomos ter concernido a Haitzmann. 
Embora empreguemos como sinônimos os dois conceitos: histeria de angústia e histeria masculina, o primeiro é preferível porque o termo angústia diz já da situação do homem nesta afecção. Consideramos que uma comparação dos casos de Hans e Haitzmann pode revelar-se muito útil.

Roudinesco e Plon (1998, p. 244), aludem ao "desaparecimento progressivo da expressão histeria de angústia (porque) a fobia acabou sendo aceita menos como um sintoma do que como uma entidade clínica". Ter-se-ia esquecido a indicação de Freud? A este respeito supomos o seguinte: quer a histeria de angústia tenha evoluído para o sintoma fóbico, quer para uma mistura com a histeria de conversão, a história do desenvolvimento, nos dois casos, resultaria em uma posição atípica no homem. A atipia é aqui definida seja em relação à heterossexualidade, situação em que o Édipo é mais bem estruturado quanto à homossexualidade de ordem narcísica. Isto se relaciona respectivamente a Haitzmann e a Hans.

Definimos o que é típico na heterossexualidade pelo efeito do recalque quanto à bissexualidade constitucional. Para Freud, a bissexualidade existe nos dois sexos e, em cada um, ela implica dois aspectos em relação ao complexo de Édipo: um positivo e outro negativo. Isto ocorre nas atitudes masculina e feminina, tanto do menino como da menina, em relação aos modelos sexuais que o casal parental representa. Uma vez que a identificação com o genitor do mesmo sexo implica não somente os sentimentos hostis de rivalidade, mas também o amor pelo qual, por vezes, a criança deseja substituir o genitor do outro sexo, o recalque é o que faz sucumbir isso que nega a identificação do menino com o pai e a da menina com a mãe.

Em “Análise terminável e interminável”, Freud (1975[1937]) especificou o de que se trata nos dois sexos. Quanto à feminilidade: no que concerne ao desejo de uma mulher, a lógica implicada é a seguinte:

[o recalque faz ceder a] inveja do pênis ${ }^{7}-$ um esforço positivo por possuir um órgão genital masculino. [Após a fase fálica, tal se converterá no] desejo de ter um bebê e de um marido que possui um pênis. [A heterossexualidade do homem é conseqüência do] protesto masculino. [Isso traduz essencialmente o] repúdio à feminilidade: [repúdio a situar-se sexualmente na posição de uma mulher] (FREUD, 1975[1937], p. 285).

Desde a primeira infância, portanto, “a atitude passiva [...] que pressupõe a aceitação da castração (em si), é energicamente recalcada" (FREUD, 1975[1937], p. 285).

Lacan (1981, p. 201, tradução nossa) discorreu sobre o que é típico e o que não o é na masculinidade: ${ }^{8}$

Na medida em que, no homem, a realização edipiana é mais bem estruturada, a questão histérica tem menos chance de se pôr. Todavia, se ela ocorre qual será? Há aqui a mesma 
dissimetria que no Édipo - o histérico, homem e mulher, implica a mesma questão. A questão do histérico macho concerne também à posição feminina.

A respeito da histeria masculina, consideramos duas indicações encontradas no artigo "Fantasias histéricas e sua relação com a bissexualidade" (FREUD, 1976[1908]). A primeira concerne à "fantasia" histérica que "se origina de um impulso homossexual"; a segunda implica a sétima fórmula enunciada por Freud (1976[1908], p. 167-168):

Os sintomas histéricos surgem como uma conciliação entre dois impulsos afetivos e instintuais ${ }^{9}$ opostos, um dos quais tenta expressar um instinto componente ou (relativo) à constituição sexual, enquanto o outro tenta suprimi-lo.

O que destas indicações implicaria Hans e Haitzmann? Supomos que, nos dois casos, o instinto relativo à constituição sexual seria uma situação edipiana masculina. De fato, nos dois homens, houve um primeiro momento em que os sentimentos de amor foram dirigidos à mãe, ${ }^{10}$ fato que ilustraria uma identificação com o pai e uma fantasia sexual ativa. Em um segundo momento, esse amor teria sido parcialmente deslocado para o pai. A este novo amor se contraporia algo que tentaria suprimi-lo. A tendência oposta procederia do protesto masculino em Haitzmann; em Hans, ela se originaria no medo à castração.

Todavia, consideraremos algo relativo ao destino da agressividade nos dois homens. Os sentimentos hostis e ciumentos em relação ao pai são a expressão da ambivalência vivida na situação edípica. Segundo Assoun (1997, p. 236, tradução nossa), trata-se nesta ambivalência do que fomenta "a dualidade DeusDiabo, [quer dizer, esta] disposição hostil que odeia, teme e se queixa do (pai) [é a mesma que se expressa] na criação do Diabo, [...] no gosto pelas caricaturas do mestre abominado, [...] na imagem do ladrão e nas zoofobias". Como veremos adiante, diferentemente do que ocorreu com Hans, a disposição aludida acarretou a crença de Haitzmann em um pacto com o Diabo. Por quê?

As duas situações implicam ora a ambivalência, ora uma distinção. Conforme veremos com Freud, o pequeno Hans desistiu de sua agressividade para com o pai, temendo ser castrado. Haitzmann, por outro lado, movido pelo protesto masculino, recorreu a um pacto com o Diabo. Admitimos com Assoun (1997, p. 236, tradução nossa), que se expresse aí a "crença em um Ser supremo e malvado, segundo a qual, o pai primitivo originário (der primitive Urvater) tinha sido um ser de maldade sem limites".

Relacionamos o que concerniu a Hans a uma distinção feita por Freud em uma das sessões da Sociedade Psicanalítica de Viena (FREUD apud DELRIEU, 1997). Ele sugeriu que havia dois tipos de homossexualidade masculina: "(1) aquela de quem se toma a si mesmo como objeto de amor e (2) aquela dos que escolhem o pai" (FREUD apud DELRIEU, 1997, p. 1433). De fato, há uma diferença entre o que acontece na homossexualidade de ordem narcísica e o que 
ocorre naquela que supomos ter origem histérica. A primeira refere-se a quem se elege a si mesmo como modelo de amor; a segunda implica um amor inicial pela mãe que depois foi deslocado para o pai.

O fato de haver amor pelo pai em Hans é semelhante ao que aconteceu com Leonardo da Vinci. Todavia, a respeito deste último, Freud (1970[1910], p. 92) afirmou o seguinte:

O amor da criança por sua mãe não pode mais continuar a se desenvolver conscientemente - ele sucumbe à repressão. $\mathrm{O}$ menino reprime o seu amor pela mãe; coloca-se em seu lugar, identifica-se com ela, e toma a si próprio como modelo a que devem assemelhar-se os novos objetos de seu amor. Desse modo, ele transformou-se em um homossexual. O que de fato aconteceu, foi um retorno ao auto-erotismo, pois os meninos que ele agora ama à medida que cresce, são apenas figuras substitutivas e lembranças de si próprio durante a infância - meninos que ele ama da maneira que sua mãe o amava quando ele era uma criança. Encontram seus objetos de amor segundo o modelo do narcisismo, pois Narciso, segundo a lenda grega, era um jovem que preferia a sua própria imagem a qualquer outra.

Como há, em Hans, uma identificação com o pai, supomos que sua sexualidade não implicou o modelo da mãe associado a uma fantasia passiva, nem se assemelhou à homossexualidade de ordem narcísica. De fato, esta última corresponde ao que em "Alguns mecanismos neuróticos do ciúme na paranóia e no homossexualismo", Freud (1976[1922], p. 280-281) atribuiu aos casos em que:

[...] os rivais odiados [da criança: geralmente os irmãos mais velhos,] se transformaram em objetos amorosos. [O que resultou daí foi induzido pela mãe que estabeleceu] outro rapaz $[\ldots]$ como modelo. [...] A tendência à escolha narcísica de objeto foi assim estimulada e, após uma breve fase de agudos ciúmes, o rival se torna um objeto amoroso.

Consideramos que tais situações correspondam àquilo que, com Sadger, Freud (1970[1910]) pôde inferir sobre o papel das mães no Édipo dos filhos. Trata-se de mulheres "muitas vezes masculinizadas, mulheres com enérgicos traços de caráter e capazes de deslocar o pai do lugar que lhe corresponde" (FREUD, 1970[1910], p. 91). A situação de Hans é outra, talvez decorrente do que Freud (1970[1910], p. 105) atribuiu à genitora de Leonardo da Vinci: "como todas as mãe frustradas [esta mulher] substituiu o marido pelo filho pequeno, e pelo precoce amadurecimento de seu erotismo, privou-o de uma parte de sua masculinidade". Voltemos a Hans e Haitzmann, respectivamente. 


\section{AMor e Medo em RelaÇão ho PAi Na histeria de ANGústia}

O pequeno Hans, com cinco anos, foi encaminhado a Freud por seu pai ${ }^{11}$ que estava preocupado com um sintoma que o genitor supunha decorrer de uma “superexcitação sexual devida à ternura excessiva da mãe" (FREUD, 1976[1909], p. 34) da criança. Nas palavras deste pai, a mãe mimava muito Hans: à noite, ele tornava-se "muito sentimental" e dizia algo assim: "imagine se eu não tivesse uma mamãe ou imagine se você fosse embora. [...] Infelizmente, sempre que ele mergulhava em um sentimentalismo desses, sua mãe costumava levá-lo para a cama com ela"12 (FREUD, 1976[1909], p. 34).

De acordo com Freud (1976[1909]), o sintoma era este: Hans receava que um cavalo o mordesse na rua. Na ocasião, Hans vinha assustando-se com a ideia de um "grande pênis" (FREUD, 1976[1909], p. 33). Em idade precoce ele tinha notado como os cavalos são dotados de grandes pênis e deduzira que sua mãe, por ser grande, "também deveria ter um pipi” (FREUD, 1976[1909], p. 33) como o cavalo. Estes receios infantis culminavam em um desânimo manifestado à noite. A questão que se esboçava aí era relativa à diferença sexual sem dúvida, mas já havia nela, algo que prenunciava um caso singular de escolha objetal.

No texto "Repressão", Freud (1974[1915], p. 178-179) disse que, na histeria de angústia, o que sucumbe ao recalque é uma "atitude libidinal para com o pai [acoplada] ao medo dele". Como o pai não aparecerá mais como objeto da libido, substituindo-o, "encontramos num lugar correspondente um animal que se presta, de modo mais ou menos adequado, a ser um objeto de ansiedade" (FREUD, 1974[1915], p. 178-179).Quer dizer: como o fator quantitativo atrelado à atitude libidinal não desapareceu, este medo corresponde a "uma exigência de amor feita ao pai" (FREUD, 1974[1915], p. 178-179).

De fato, como para Freud (1974[1915], p. 177, grifo do autor), o destino da "quota de afeto [...] é muito mais importante do que a vicissitude da idéia", isto é, do representante ideativo, e já que o recalque falha em poupar o desprazer, "o trabalho da neurose não cessa [...] o que se segue é uma tentativa de fuga - a formação da fobia propriamente dita, de um grande número de evitações destinadas a impedir a liberação da ansiedade".

Segundo Freud (1976[1909], p. 143-144):

[Hans fora] alcançado por uma grande onda [do recalque que apanhou precisamente os] componentes sexuais que eram dominantes [...]: sentimentos hostis e ciumentos em relação a seu pai, e impulsos sádicos (premonições, como era o caso da cópula) em relação a sua mãe. [Em nota, o Psicanalista acrescentou que o pai desta criança observou que,] simultaneamente com este (recalque), certa quantidade de sublimação teve início. [Desde a época do começo da angústia, o menino começou a] mostrar um interesse maior por música e a desenvolver seu dom musical herdado. ${ }^{13}$ 
Freud voltou a falar sobre este assunto no texto "Inibições, sintomas e ansiedade". Nesta ocasião, ele asseverou que "não podia haver dúvida alguma" de que o recalcado em Hans tinha sido um "impulso hostil contra o pai" (FREUD, $1976[1926$ (1925)], p. 128). A hostilidade fora recalcada "pelo processo de ser transformada em seu oposto". Dessa forma, em vez de Hans dirigir sua agressividade em relação ao pai, "surgiu agressividade (sob a forma de vingança) por parte do pai" (FREUD, 1976[1926 (1925)], p. 128). O Psicanalista conclui que "a força motriz" do recalque se atrelava ao "temor da castração iminente. (O pequeno) desistiu de sua agressividade para com o pai, temendo ser castrado" (FREUD, 1976[1926 (1925)], p. 128). Tal se refere também à ambivalência em relação ao pai.

Freud (1976[1926 (1925)], p. 118) admitira anteriormente que Hans "era realmente um pequeno Édipo que queria ter seu pai 'fora do caminho' queria livrar-se dele". Esse desejo tinha surgido durante umas férias de verão em que a presença e a ausência alternativa do pai tinham "atraído a atenção de Hans para a condição da qual dependia a intimidade com a mãe" (FREUD, 1976[1926(1925)], p. 118). Nessa época seu desejo era aquele de o pai "ir embora". Posteriormente, esse desejo tomou a forma "de que seu pai devia ficar permanentemente longe que ele devia estar morto" (FREUD, 1976[1926 (1925)], p. 118). Como segundo Freud (1976[1926 (1925)], p. 118), esta atitude atrelou-se também ao "medo de ser mordido por um cavalo branco", podemos perceber o que da ambivalência vivida, atinava para a fantasia de uma retaliação por parte do pai.

Todavia, para Freud (1976[1926 (1925)], p. 119-120) Hans “não era dessas crianças que, na sua idade, ainda dão livre curso para a propensão à crueldade e à violência". Ao contrário, ele tinha uma disposição incomum de afeição. "Seu pai relatou que a transformação das tendências agressivas em sentimentos de piedade (tinham ocorrido) muito cedo nele" (FREUD, 1976[1926 (1925)], p. 119-120). De fato, muito antes de desenvolver a fobia, "ele tinha ficado inquieto" quando vira serem batidos os cavalos de um carrossel. Ademais, ele nunca ficava insensível ao ver uma pessoa chorar. Havia em Hans um "sadismo suprimido" (FREUD, $1976[1926$ (1925)], p. 119-120). Quando ele batia no pai, logo depois beijava o lugar em tinha batido. Freud viu nisso uma objeção do intelecto da criança.

Havia também, em Hans, uma corrente de ternura relativa às meninas. Segundo Freud, ela se manifestou a primeira vez quando, com três anos e nove meses de idade, este menino foi apresentado às filhas de um amigo de seu pai. As duas meninas tinham cerca de dez anos de idade.

Hans sentou-se ao lado delas [e] as contemplava com admiração, [embora esse] procedimento não lhes causasse a menor impressão. [Na consciência de sua idade, as duas garotas] olhavam de cima para aquele garotinho. [Por algumas semanas se relembrando de onde as tinha conhecido, Hans perguntava]: quando é que vou voltar ao rinque (de patinação) para ver as minhas meninas? (FREUD, 1976[1909], p. 25). 
Quando Hans tinha quatro anos, houve um "amor à longa distância":

Hans descobriu uma menina de sete ou oito anos de idade. Ele ia sentar-se no degrau que dava para o pátio, de modo a admirá-la e lá ficava horas a fio. Às quatro horas da tarde, particularmente quando a menina chegava da escola, não se podia retê-lo na sala, e nada era capaz de induzi-lo a abandonar seu posto de observação. Certa vez, quando a menina deixou de aparecer à janela na hora habitual, Hans ficou bastante inquieto, e molestava os empregados com perguntas - "quando a menina vai vir? Onde está minha menina?" Enfim, quando ela aparecia, ele ficava felicíssimo e jamais retirava os olhos (de seu) apartamento (FREUD, 1976[1909], p. 25-26).

Freud explicou esta admiração, pela falta de companheiros de folguedo de Hans, companheiros de qualquer dos dois sexos. Eis o que ele entreviu antecipadamente sobre o futuro do pequeno: "no seu desenvolvimento subseqüente, $[. .$.$] não$ foi para a homossexualidade [que a criança prosseguiu, mas para] uma masculinidade enérgica, com traços de poligamia" (FREUD, 1976[1909], p. 117-118).

Vale acrescentar dois pontos a este respeito. O primeiro concerne ao complexo de castração. Para Freud (1976[1909], p. 31), Hans "reconheceu a diferença entre os genitais masculinos e femininos, em vez de negar sua existência". Tal foi inferido com base no fato de o pequeno Hans ter rido ao rever sua irmãzinha nua no banho. Quando lhe perguntaram sobre esta reação, o menino respondeu:

"porque seu pipi é tão bonitinho". Na realidade, [disse Freud]: a resposta não era sincera. O pipi dela lhe parecia engraçado. [...] Foi essa a primeira vez em que Hans reconheceu a diferença entre os genitais masculinos e femininos, em vez de negar ${ }^{14}$ a sua existência. (FREUD, 1976[1909], p. 31, grifo do autor).

O Psicanalista reiterou também a ideia da masculinidade de Hans: referindo-se a uma brincadeira (deste último) de trotar, deixar-se cair, espernear e relinchar, qual o cavalo relativo à sua fobia, ele (FREUD, 1976[1909, p. 61) afirmou: "[Hans] era o cavalo e mordia seu pai; assim, ele se identificava com seu pai".

O segundo ponto se refere ao casal parental. Freud (1976[1909]) diz que, quanto ao que supunha haver sexualmente entre seu pai e sua mãe, Hans desenvolveu uma versão sádica do coito. Ele fantasiava haver "algum ato de violência executado" (FREUD, 1976[1909], p. 140) na mãe. Como se verá mais adiante, essa fantasia não deixará de exercer sua influência numa escolha de objeto homossexual.

Eis em que, quanto à diferença sexual, resultou a poderosa onda do recalque no pequeno Hans:

Apesar de as sensações do seu pênis o terem colocado no caminho de pressupor uma vagina, ele ainda não podia 


\begin{abstract}
O recalque e a castração na histeria de angústia: o pequeno Hans e Christoph Haitzmann
resolver o problema, pois em sua experiência não existia tal coisa como o seu pipi exigia. Ao contrário, sua convicção de que sua mãe possuía um pênis, tal como ele, ficou no caminho de qualquer solução. Sua tentativa de descobrir o que era que tinha de ser feito com sua mãe, a fim de que ela pudesse ter filhos, afundou para seu inconsciente (FREUD, 1976[1909], p. 140).
\end{abstract}

Freud (1976[1909], p. 150) chegou a dizer que se o caso tivesse sido "inteiramente entregue" em suas mãos, ele teria confirmado certas "premonições instintivas", explicando a Hans sobre "a existência da vagina e da cópula". Assim ele teria diminuído ainda mais o "resíduo não resolvido e posto fim à sua torrente de perguntas" (FREUD, 1976[1909], p. 150). Freud (1976[1909], p. 150) estava convencido de que "essa nova parcela de esclarecimento" não teria feito Hans "nem perder seu amor por sua mãe ${ }^{15}$, nem sua própria natureza de criança".

Tendo perdido (parcialmente) o amor pela mãe, para onde se dirigiria a escolha de objeto no pequeno Hans? Parece delinear uma resposta, a fantasia do bombeiro que, segundo Freud (1976[1909], p. 105), "com sinais de grande resistência" Hans relatou a seu pai.

\begin{abstract}
"Escuta", disse (Hans ao pai), eu pensei uma coisa hoje. O bombeiro veio; e primeiro ele retirou o meu traseiro com um par de pinças, e depois me deu outro, e depois fez o mesmo com o meu pipi. Ele disse: 'Deixe-me ver o seu traseiro!' Tive que dar uma volta, e ele o levou; depois disse: 'Deixeme ver o seu pipi”! (Para Freud), o pai de Hans compreendeu a natureza desta fantasia apaixonada, e não hesitou um momento quanto à única interpretação que ela podia admitir: "ele te deu um pipi maior e um traseiro maior ${ }^{16 "}$. 'Hans: "É". (O pai): "como os do papai; porque você gostaria de ser o papai". (Hans): "Sim, eu gostaria de ter um bigode como o seu e cabelos como os seus". (O pai): ele apontou parta os cabelos do meu peito (FREUD, 1976[1909], p. 105).
\end{abstract}

O fato de Freud ter-se referido à "fantasia apaixonada" nesse caso não é sem importância, tampouco a preocupação interpretativa do pai de Hans. ${ }^{17}$ Isto se refere a uma expectativa positiva quanto à identificação da criança mediante o modelo sexual do pai. De fato, o Psicanalista já entrevira uma tendência homossexual se esboçar no pequeno Hans. Comentaremos sobre dois episódios a este respeito.

Segundo Freud (1976[1909]), um dia um primo de cinco anos veio visitar Hans que tinha então quatro anos. A este primo, quando lhe dava um de seus abraços ternos, Hans disse: "eu gosto tanto de você" (1976[1909], p. 25). Depois de afirmar que este era o primeiro traço de homossexualidade percebido nesta criança e que não seria o último, Freud (1976[1909], p. 25) acrescentou: "o pequeno Hans parece ser um modelo positivo de todos os vícios". ${ }^{18}$ Freud (1976 [1909], p. 26) relata também que, em outra ocasião, tendo sido interrogado - " "Das meni- 
nas, de quem você gosta mais'? -, Hans respondeu: 'Fritzl!' ${ }^{19}$ [Ao mesmo tempo, Hans] tratava as meninas de forma muitíssimo agressiva, masculina e arrogante, abraçando-as e beijando-as com sinceridade".

Supomos que a fantasia do bombeiro possa remeter à história do desenvolvimento em Hans: o amor inicial pela mãe foi parcialmente transferido para o pai e daí para novos objetos homossexuais. Todavia, resta ainda uma pergunta a nos fazer: uma vez que esta criança reconhecia a diferença sexual, como podemos entender a convicção que Freud diz ter ficado a caminho de qualquer solução, convicção de que sua mãe teria um pênis? Tal poderia referir-se a outra razão? ${ }^{20} \mathrm{O}$ que dizem outros psicanalistas a esse respeito? Depois de comentar o que eles afirmaram, tentaremos justificar nossa suposição, mediante o que já aludimos quanto à lógica da sétima fórmula do artigo "Fantasias histéricas e sua relação com a bissexualidade".

Para Lacan (1994, p. 414, tradução nossa) o pequeno Hans se situava “em certa posição apassivada e, qualquer que [fosse] a legalidade heterossexual de seu objeto, nós não poderíamos considerar que ela esgotasse a legitimidade de sua posição". Ele se aproxima mais de um tipo que não parecerá "estranho em nossa época $[. .$.$] , aquele destes jovens atraentes [...] que aguardam a iniciativa vir do$ outro lado, esperam que se lhes tirem as calças" (LACAN, 1994, p. 414, tradução nossa). Em uma conferência feita em Bruxelas, no dia 26 de fevereiro de 1977, Lacan falou que dentre os homens histéricos: "não se encontra um só que não seja uma fêmea (tradução nossa)".

Mais adiante, Lacan disse:

O pequeno Hans não teve que perder seu pênis, uma vez que [...], ele nunca o adquiriu, em nenhum momento. $\mathrm{O}$ fato de (ele) ter-se identificado com o falo materno, não quer dizer que ele possa assumir, propriamente falando, a sua função. Não há nenhuma fase de simbolização do pênis. De alguma forma, o pênis fica à margem, desengrenado, como algo que não foi nunca senão difamado, reprovado pela mãe. $\mathrm{O}$ que se produziu não lhe permite integrar sua masculinidade por nenhum mecanismo senão mediante uma identificação com o falo materno que é, outrossim, de ordem diferente daquela do supereu, esta função, sem dúvida perturbadora, mas equilibradora também que é o supereu (LACAN, 1994, p. 415, tradução nossa).

Segundo Nasio (1991, p. 45), psicanalista que distingue entre histeria masculina e fobia, os homens histéricos são aqueles que manifestam um "baixo interesse pelas mulheres ou, mais exatamente, uma baixa pulsão de penetrar o corpo da mulher". Ademais eles são, "narcisistas, ${ }^{21}$ exibicionistas, por vezes muito sedutores e (apresentam) um grau variável de homossexualidade e masturbação" (NASIO, 1991, p. 45). Consideramos que esta situação remete a uma teoria sádica do coito: fantasia de origem infantil que, no adulto histérico, culmina no temor a fazer mal a uma mulher, razão de o ato sexual não lhe interessar. 
A este respeito seria mais exato dizer com Winter (1998, p. 65-66, tradução nossa): o ato sexual não dá ao homem histérico "nenhum prazer. Tal constitui para ele, algo quase da ordem de uma obrigação [corvée]. ${ }^{22}$ Porém, o que lhe interessa no mais alto grau, é o gozo feminino que ele vive como infinito, infinito como a seqüência dos números". Para Winter (1998, p. 187, tradução nossa), "o homem histérico sofre por estar preso entre duas fantasias, ${ }^{23} \mathrm{sem}$ poder ceder a uma nem à outra".

Tudo se passa como se o histérico estivesse preso entre uma fantasia masculina, comodamente chamada [...] ativa e uma fantasia feminina [...] comodamente chamada passiva. Todavia, o histérico não se situa enquanto objeto mediante esta fantasia. Quer dizer, no momento em que, para ele, surgiria o risco de ser este objeto pequeno $a,[\ldots]$ no momento em que ele poderia estar na posição de objeto em sua fantasia, produz-se uma mudança, no próprio interior do inconsciente. Esta faz com que ele mude de fantasia. No fundo, poder-seia dizer que o histérico erra entre duas fantasias: ele é um errante entre a fantasia da masculinidade e a fantasia da feminilidade. Isso faz com que, clinicamente, ele não seja jamais tão masculino quando se pensa feminino, e também jamais tão feminino quando se pensa absolutamente viril (WINTER, 1998, p. 187, tradução nossa, grifo nosso).

Conforme Juliet Mitchell (2006, p. 46) o complexo de Édipo negativo masculino, ou seja, "a passividade do homem em relação ao pai teve de suportar o ônus de explicar tanto a histeria masculina quanto a homossexualidade". Os dois fenômenos foram unidos com uma "freqüência excessiva", todavia, "a histeria é essencialmente bissexual" (MITCHELL, 2006, p. 46). ${ }^{24}$ Um retorno ao que inferimos anteriormente de Freud e ao que supomos quanto a Hans, talvez esclareça certa diferença quanto às perspectivas apresentadas acima.

Eis algumas conclusões em relação a Hans. Nelas consideramos dois pontos de que Freud falou em "Fantasias histéricas e sua relação com a bissexualidade"; repetimos: (a) na histeria masculina, existe uma fantasia que se origina de um impulso homossexual, (b) os sintomas histéricos surgem como uma conciliação entre dois impulsos afetivos e instintuais opostos, um dos quais tenta expressar um instinto relativo à constituição sexual, isto é, relativo ao sexo biológico, enquanto o outro, tenta suprimi-lo.

Em Hans a oposição afetiva e instintual de ordem histérica concerniria a uma angústia que poderíamos chamar de existencial. ${ }^{25}$ Uma vez que houve recalque, um conflito se daria entre o eu e o isso ${ }^{26}$ e conteria uma tendência heterossexual oposta a outra de origem homossexual, todas as duas oriundas da bissexualidade constitucional. O complexo de Édipo, a situação inicial de identificação com o pai e o amor pela mãe corresponderiam a uma condição original. Em relação a esta última, contudo, a versão infantil sádica do coito acarretaria uma mudança. 
Como já vimos com Nasio (1991) e Winter (1998), de fato, a persistência da fantasia do coito sádico, no adulto histérico, resulta seja em um baixo interesse genital de penetrar o corpo da mulher, seja em insatisfação quanto ao ato sexual. Winter afirma que este último não dá ao homem histérico nenhum prazer, é quase da ordem de uma obrigação. Estes dados têm a ver também com o que o Nasio chamou de graus variáveis de homossexualidade no homem histérico.

Ora, uma vez que o pequeno Hans, quanto à mãe, fantasiava haver violência no ato sexual, ${ }^{27}$ supomos que seu desenvolvimento posterior não se teria dado para uma "masculinidade enérgica com traços de poligamia", isto é, para uma heterossexualidade tão compulsória, mas para o que a fantasia do bombeiro indicaria. Para esta última, além do amor ao pai, teriam convergido as manifestações de homossexualidade que Freud já teria percebido na criança: aquela quanto ao primo de cinco anos e outra referente ao amiguinho Fritzl. $\mathrm{O}$ fato de o pequeno Hans ter desistido de sua agressividade quanto ao pai, teria facilitado esta orientação sexual.

Esta situação mostraria que o amor inicial pela mãe teve que ser transposto para o pai, eleito a partir de então, como novo objeto de desejo. Todavia, como a realização desse novo amor, em outros objetos de desejo, ${ }^{28}$ sempre acarretaria o medo da castração ${ }^{29}$ (em si) - porquanto não haveria uma posição feminina no homem histérico -, deduzimos que a transposição aludida teria sido apenas parcial. Isso implicaria, então, que a eleição de objeto homossexual não existiria tampouco sem algo vivido anteriormente que se lhe oporia: a tendência heterossexual da identificação com o pai.

Encontramos uma diferença patente entre esta situação e aquela da homossexualidade de ordem narcísica. Ela se refere ao papel da mãe no complexo de Édipo, papel em relação àquele de seu marido. Nenhum dos dados referidos mostra que a mãe de Hans fosse uma mulher masculinizada e capaz de deslocar o marido do lugar que lhe é devido. O que podemos inferir dela é que em sua ternura excessiva, esta mulher teria substituído o marido pelo filho pequeno. O precoce amadurecimento desse erotismo teria privado Hans de uma parte de sua masculinidade.

Acabamos de falar sobre o caso em que a histeria de angústia evoluiu mais e mais para a fobia sem, no entanto, combinar-se com a histeria de conversão. Supomos ter acontecido aí, algo de que Freud (1976 [1907], p. 127, 128) falou em "Atos obsessivos e práticas religiosas": assim como para o obsessivo "o cerimonial surge como um ato de defesa ou de segurança, uma medida protetora", uma "fobia evita um ataque histérico". O ataque em questão seria aquele que implicaria uma mistura com os sintomas da histeria de conversão.

Uma vez que a situação de Haitzmann teria implicado esta mistura, o que de diferente de Hans poderíamos esperar? Como já exposto, supomos ter havido um primeiro momento em que os sentimentos de amor foram dirigidos à mãe, o que ilustraria uma identificação com o pai e uma fantasia sexual ativa. Em um segundo momento, esse amor teria sido parcialmente deslocado para o pai. A este novo amor homossexual, se contraporia algo que tentaria suprimi-lo. Esta tendência oposta procederia do protesto masculino. 
A diferença que houve entre Hans e Haitzmann se deveu ao destino dos sentimentos hostis e ciumentos em relação ao pai. Não tendo havido um sadismo suprimido em Haitzmann, a expressão da ambivalência da situação edípica, mediante o protesto masculino, teria fomentado não somente a fantasia de uma "retaliação" dirigida ao pai, mas também uma forma de agressividade paroxística: o recurso ao pacto com o Diabo. ${ }^{30}$

\section{A situação de Haitzmann}

Trata-se de um pintor bávaro do século XVII cuja morte do pai o fizera cair em uma depressão melancólica com perda da capacidade para o trabalho. Para recuperar-se deste estado, Haitzmann decidiu fazer um pacto escrito com sangue: o jovem homem se comprometeu a entregar-se de corpo e alma ao demônio, após nove anos. Antes de este prazo expirar, Haitzmann se arrependeu e se convenceu de que somente "a graça da Mãe de Deus poderia salvá-lo, obrigando o Maligno a liberá-lo (de seu) compromisso". Ele foi então trazido ao "santuário de Mariazell, ${ }^{31}$ lugar de peregrinação (situado) a cerca de 130 quilômetros a sudoeste de Viena" (FREUD, 1976 [1923 (1922), p. 93-95).

Depois de um tempo de penitência e oração ali, Haitzmann foi morar em Viena com uma irmã casada, porém, reivindicando a devolução pelo Demônio de outro pacto escrito a tinta, retornou a Mariazell e ,posteriormente, ingressou na Ordem dos Irmãos Hospitalares. O Padre Provincial desta última comunicou que Haitzmann:

[...] havia sido repetidamente tentado pelo Espírito Mau, que tentara seduzi-lo a fazer um novo pacto (embora isso só acontecesse "quando ele bebera vinho um pouco em demasia"). [Haitzmann morreu de] febre héctica no ano de 1700 no mesmo Mosteiro (FREUD, 1976 [1923 (1922), p. 97-98).

O que Freud (1976 [1923 (1922), p. 95-96) analisou sobre esta situação, proveio da leitura de um manuscrito que consistia de três partes: (1) na primeira, encontravam-se duas cenas coloridas representando a assinatura do pacto com o Demônio, e redenção quanto àquele, e oito quadros ${ }^{32}$ também coloridos representando as aparições subseqüentes do Demônio. Referente a cada um deles havia uma breve legenda em alemão; (2) o Trophaeum Mariano-Cellense real escrito em Latim, trabalho de um compilador clerical que termina com o depoimento de um abade e (3) o diário do pintor, escrito no alemão da época.

Não nos deteremos nos detalhes com que os pactos aludidos foram escritos, mas ao que atina para a situação da neurose em Haitzmann. Para Freud (1976[1923 (1922), p.111-112) não é fato incomum o homem ser acometido de depressão melancólica e de inibição em seu trabalho, após a morte de seu pai. Quando isso acontece, porém, podemos inferir que ele "fora ligado ao pai por um amor especialmente intenso" (FREUD, 1976[1923 (1922), p.111-112). A melancolia surge ,então ,como "forma neurótica do luto" (FREUD, 1976[1923 (1922), 
p.111-112). Todavia, não devemos pensar que a relação com este pai tenha sido apenas de amor. Ao contrário, o "luto pela perda do pai tem mais probabilidade de se transformar em melancolia, quanto mais sua atitude para com ele portar a marca da ambivalência" (FREUD, 1976[1923 (1922), p.111-112).

Realmente, conforme o Psicanalista,

Quando um menino desenha rostos grotescos e caricaturas, podemos francamente demonstrarque [aí ele] está escarnecendo de seu pai, e quando uma pessoa de qualquer sexo tem medo de ladrões e arrombadores à noite, não é difícil identificá-los como partes expelidas (split off) do pai. Também os animais que aparecem nas fobias [...] das crianças, são muito amiúde substitutos paternos, como foram os animais totêmicos das épocas primevas. Que o demônio, porém, seja uma duplicata do pai e possa agir como substituto dele, não fora demonstrado tão claramente como na neurose demoníaca desse pintor do Século XVII (FREUD, 1976[1923 (1922), p. 111).

Por um momento, pareceu muito estranho ao Psicanalista, a ideia de Haitzmann de aceitar o demônio como substituto do pai que amara. Diferentemente do pequeno Hans que, temendo ser castrado, desistira de sua agressividade para com o pai, em Haitzmann o protesto masculino operou de forma paroxística. Apesar da intervenção pedida aos Padres, mediante a sua crença na Mãe de Deus, o tema do pacto com o Demônio nunca deixou de existir. Embora haja atipia em relação aos homens em que o Édipo é mais bem estruturado, a insistência do tema deste pacto não indicaria nenhuma apassivação, pelo contrário, ela implicaria o recrudescimento da situação original de identificação com o pai. Trata-se de uma disposição hostil que, ao mesmo tempo, odeia, teme e se queixa do pai.

Admitimos, portanto, com Assoun (1997, p. 236, tradução nossa) que, não havendo “mais nada a esperar do 'pai do alto' [foi o] dirigir-se a outra face, aquela 'do pai de baixo' [o que permitiu a Haitzmann] reemergir de sua melancolia”. Enquanto em Hans havia um sadismo suprimido, ou seja, a transformação da agressividade em sentimentos de piedade, Haitzmann fantasiou uma espécie "retaliação" quanto ao pai: "devolveu-lhe" um efeito de seu conflito. Tal aspecto se manifestou precisamente em suas pinturas do Demônio. A revolta contra a castração (em si próprio) o fez recorrer à fantasia de castrar o pai e transformá-lo em mulher.

Segundo Freud (1976[1923 (1922)]) realmente, as relações de Haitzmann com o Demônio, aliás, suas visões possuíam uma referência sexual. Embora na primeira delas, aquele aparecera como um "honesto cidadão, [na segunda, ele] estava nu e disforme e tinha dois pares de seios femininos. Em nenhuma das suas aparições subsequentes os seios estão ausentes, quer como par único ou duplo" (FREUD, 1976[1923 (1922)], p. 114). Somente em uma delas o Demônio exibe "um grande pênis terminando por uma serpente. [...] Nunca há qualquer indicação dos órgãos genitais femininos" (FREUD, 1976[1923 (1922)], p. 114). ${ }^{33}$ 
Os seios com que Haitzmann representou o Demônio corresponderiam, de fato, a uma projeção de sua própria feminilidade sobre o substituto paterno. Freud (1976[1923 (1922)], p. 214) mostrou que o Demônio em Haitzmann, na realidade era "um substituto direto do pai [a quem o jovem homem fora ligado] por um amor especialmente intenso". Todavia, a segunda explicação dos acréscimos femininos ao corpo do diabo não teria mais um sentido hostil, mas afetuoso. Freud percebeu neles uma indicação de que os sentimentos ternos da criança pela mãe foram deslocados para o pai. ${ }^{34}$ Seios grandes são as características sexuais positivas da mãe (FREUD, 1976[1923 (1922)], p. 115-116).

De fato, para Freud, a atitude feminina de um menino para com o pai sofre o recalque tão logo ele compreenda que sua rivalidade com uma mulher pelo amor do pai tem como precondição, a perda de seus próprios órgãos genitais. O repúdio da atitude feminina constitui, assim, o resultado de uma revolta contra a castração.

Esta revolta é distinguível também não somente do que acontece na paranóia ${ }^{35}$ como daquilo que em "O Problema econômico do masoquismo", Freud (1976[1924], p. 202) atribuiu aos "desempenhos dos pervertidos masoquistas". Para Freud (1976[1924], p. 202), quanto às fantasias masoquistas, "de imediato se descobre que elas colocam o indivíduo numa situação caracteristicamente feminina; elas significam, assim, ser castrado, ou ser copulado, ou dar à luz um bebê".

Em conformidade com o que acabamos de dizer com Freud, ${ }^{36}$ sugerimos outra leitura para a interpretação de Freud (1976 [1922 (1923)]) sobre os nove anos do pacto de Haitzmann com o Demônio. Correlacionando os nove anos deste pacto com os nove meses da gravidez, Freud tinha dito o seguinte: "aquilo contra o que (Haitzmann) está se rebelando é a sua atitude feminina para com o pai, que culmina pela fantasia de dar-lhe um filho" (FREUD, 1976 [1922 (1923)], p. 115). Como desenvolvido alhures (BARROCAS, 2002), se há recalque e um protesto masculino em Haitzmann, os nove anos aludidos remetem preferivelmente a uma vontade de renascimento, de recomeço ainda que sob a condição de filho do demônio.

$\mathrm{O}$ caso de Haitzmann se assemelha àquele dos homens histéricos de que falamos com Winter e Nasio. Como supomos ter havido a persistência da fantasia infantil do coito sádico, não há aí nada de comparável com a expressão de uma heterossexualidade típica, tampouco com a homossexualidade qual aquela de Hans. O pintor bávaro parece ter vivido preso entre duas fantasias, sem poder ceder a uma nem a outra; o ato sexual não lhe teria dado nenhum prazer. Supomos que lhe teria proporcionado alguma satisfação ora a pintura (embora referida também à face demoníaca do pai), ora a bebida. Quanto a esta, como foi dito pelo Padre Provincial da Ordem dos Irmãos Hospitalares, ele havia sido repetidamente tentado pelo Espírito Mau, que tentara seduzi-lo a fazer um novo pacto, embora isso só acontecesse quando ele bebera vinho um pouco em demasia.

Realmente, segundo Freud (1976[1923 (1922)], p. 101-103; 105), Haitzmann não se interessava por nada que, em sua fantasia, o Demônio podia lhe oferecer dentre as coisas "altamente prezadas pelos homens", ("desejos muito naturais"): 
[...] riqueza, segurança, [...] o gozo de mulheres belas. [Haitzmann não se interessava por nada disso, mas por] ser libertado de um estado de depressão [causado pela morte do pai]. Ele ficara abatido, era incapaz ou não tinha disposição de trabalhar adequadamente, e estava preocupado sobre como ganhar a vida.

Gostaríamos de acrescentar ainda algo relativo à religião que destacamos da leitura desse caso. Como, segundo Freud, (1976[1923 (1922)], p. 95; 110), o pintor bávaro estava convencido de que "só a graça da Mãe de Deus [...] poderia salvá-lo, obrigando o Maligno a liberá-lo" de seu pacto, a atitude religiosa que aí se expressaria, remeteria a "dois conjuntos de impulsos emocionais que se opunham" e teriam relação com a histeria de angústia. Tal como em outras relações com a Divindade, ocorreria aí um "problema não solucionado entre o anseio pelo pai, por um lado, e, por outro, o medo dele" (FREUD, (1976[1923 (1922)], p. 95; 110). A vida pessoal e a oposição instintual para onde teria evoluído a histeria de angústia, teriam coincidido em Haitzmann.

\section{Notas}

${ }^{1}$ Os dois casos não provêm diretamente de uma situação clínica. O que concerne a Hans, criança de cinco anos, procede de relatos e anotações feitas por seu pai que, interessado pela psicanálise, as entregou a Freud. Como este último só conversou com esta criança uma vez, não se pode falar que houve um tratamento neste caso. O que se refere a Christoph Haitzmann resulta de uma análise documental: a leitura de um manuscrito do século XVII encontrado na Biblioteca Imperial de Viena. Para Freud, este apresentava um quadro clínico semelhante ao de uma neurose.

${ }^{2}$ Os termos ansiedade e angústia serão utilizados como sinônimos.

${ }^{3}$ Referimo-nos aos estados temporários em que a função de atenção da consciência desaparece.

${ }^{4}$ Conforme as obras citadas, utilizaremos, neste texto, os termos repressão e recalque como sinônimos do que Freud chamou Verdrängung.

${ }^{5}$ Somos gratos ao Professor David Krebs que confirmou nossas traduções e esclareceu que "in den vorkommenden Krankheitsfällen" traduz-se por: 'nos casos de doença que aparecem'.

${ }^{6} \mathrm{Na}$ tradução espanhola da Editorial Biblioteca Nueva (FREUD, S. 1973 [1909], p. 1425), a palavra vorkommenden não foi traduzida. Só se considerou Krankheitsfällen: "casos patológicos". Todavia, guardou-se ali a lógica que Freud implicou.

${ }^{7}$ Segundo Juliet Mitchell (1988, p. 10), ao se referir à "inveja do pênis" e não "inveja do poder fálico", Freud "produziu uma interpretação biológica errônea". Para maior esclarecimento do que concerne à feminilidade, recomendamos também a leitura de Reflexões de uma psicanalista sobre a sexualidade feminina (CHILAND, 1993. cap. 2).

${ }^{8}$ Conforme Lacan, o homem é todo fálico, isto é, todo submetido à castração na condição de que exista pelo menos um que não esteja aí submetido: o Pai morto da história. Assim Lacan (1975, p. 70; 74, tradução nossa) concebeu a fórmula da sexuação no homem histérico: "não se é forçado quando se é macho, a se pôr do lado do todo fálico. Pode-se se pôr também do lado do não-todo, [isto é, do lado das mulheres]. Há homens que são tão bons quanto as mulheres. Isso acontece. [...] Apesar de, eu não digo seu falo, apesar do que lhes atrapalha quanto a tal, eles experimentam [éprouvent] a idéia que deve haver um gozo que situado mais além", isto é, além da função fálica.

${ }^{9}$ Por instinto entenda-se o que em outras versões da obra de Freud foi traduzido por pulsão.

${ }^{10}$ Algumas passagens dos textos que serão comentados a seguir mostrarão isso!

${ }^{11}$ Freud (1976?[1909], p. 16) diz que estes pais "haviam concordado em que, ao educar seu primeiro filho, não usariam de mais coerção do que a que fosse absolutamente necessária para manter um bom comportamento". A mãe de Hans fora paciente de Freud, anteriormente.

${ }^{12}$ Não desenvolveremos o que de frustração no casal poderia haver aí!

${ }^{13} \mathrm{O}$ pai de Hans era musicista. 
${ }^{14}$ No texto original, Freud (1969 [1909], p. 25) empregou o verbo "verleugnen": abjurar e não negar o que, em alemão, se diz "verneinen". A partir do texto "Fetichismo" de 1927, podemos dizer que, se houvesse uma Verleugnung: abjuração da castração, Hans não seria um neurótico. Seguindo estritamente a lógica empregada neste texto, mediante o verbo alemão verleugnen, Freud veio a mostrar o que acontece na perversão, agora compreensível como entidade clínica. Ocorre uma moção afirmativa da castração simultânea a outra que a nega. Achamos preferível adotar o verbo abjurar e não desmentir ou renegar. Já que renegar, etimologicamente falando, refere-se a negar uma segunda vez, e desmentir equivale a dizer a verdade quanto ao que inicialmente foi uma mentira, estes verbos não atinam para a lógica aludida por Freud.

${ }^{15}$ Segundo o que desenvolvemos aqui, esta perda foi apenas parcial. Tal será explicado mais adiante.

${ }^{16}$ Quando em seu devaneio, Hans diz que o bombeiro "fez o mesmo com o seu pipi", tal se refere a que aquele o retirou e depois lhe deu outro, qual fizera com seu traseiro.

${ }^{17}$ Percebemos aí uma suplência quanto ao papel de pai: ele representa uma posição simbólica relativa ao homem e distinta daquela referente à mãe. Não desenvolvemos o tema da suplência.

${ }^{18}$ No texto original, aparece a palavra maldade (Schlechtigkeit) e não vício: "Unser Kleine Hans scheint wirklich ein Ausbund aller Schlechtigkeit zu sein": "nosso pequeno aparece realmente como um modelo de todas as maldades" (FREUD, 1969[1909], p. 21, tradução nossa).

19 "Fritzl" ou o pequeno Frederico era um coleguinha de folguedo de Hans.

${ }^{20}$ Esta é nossa hipótese que, todavia, não será tratada completamente aqui. Não se trata de uma convicção da criança, mas de uma questão que lhe intrigaria, em um primeiro momento. Ela teria a ver com a transposição para o pai, do amor que inicialmente fora dedicado à mãe. O interrogarse sobre esta ter um pênis implicaria, portanto, não uma abjuração da castração (Verleugnung), mas o medo da castração em si: o ter que se haver com o amar um homem.

${ }^{21}$ Achamos pertinente distinguir entre o que Nasio refere ao narcisismo do homem histérico e aquilo que em "Sobre o narcisismo: uma introdução", Freud (1974[1914], p. 104) atribuiu uma perturbação no desenvolvimento libidinal nos homens "pervertidos e homossexuais".

${ }^{22}$ Corvéia em português.

${ }^{23}$ Traduzimos por fantasia - termo geralmente empregado por Freud - o que o autor disse "fantasma" (phantasme) em francês.

${ }^{24} \mathrm{~A}$ discussão sobre este assunto pode ir bem mais longe e implicar outro tema que até agora não consideramos, nem consideraremos: uma proximidade entre a histeria masculina e a paranóia.

${ }^{25}$ Tal não será aprofundado aqui.

${ }^{26}$ Conferir Freud (1976[1924], p. 189).

${ }^{27}$ Conferir seja Nota 15 , seja o que está dito no parágrafo a que esta se refere.

${ }^{28} \mathrm{~A}$ fantasia do bombeiro remete a tal.

${ }^{29}$ Isso explicaria a grande resistência com que o pequeno Hans contara ao pai, sua fantasia do bombeiro.

${ }^{30}$ Percebemos aí a "crença em um Ser supremo e malvado segundo a qual, o pai primitivo originário (der primitive Urvater) tinha sido um ser de maldade sem limites".

${ }^{31}$ Santuário "Mariano-Cellense".

${ }^{32}$ Freud acrescentou que não se tratava dos originais que foram preservados em arquivos, mas de cópias testificadas por aqueles aí implicados.

${ }^{33}$ Apesar de supor que isso tem a ver com a persistência da fantasia do coito sádico, não aprofundaremos este tema aqui.

${ }^{34}$ Isso sugere que houve previamente intensa fixação na mãe, fixação que, por sua vez, foi responsável por parte da hostilidade da criança para com o pai.

${ }^{35}$ De fato, nada em Haitzmann se assemelha ao que aconteceu com Schreber: este último decidiu acomodar-se ao delírio de uma posição feminina.

${ }^{36}$ Trata-se de texto posterior àquele sobre Haitzmann. 


\section{REFERÊNCIAS}

ASSOUN, P.-L. Psychanalyse. Paris: Presses Universitaires de France, 1997.

BARROCAS, R. L. L. Expérience mystique et jouissance: Jean de La Croix et Angelus Silésius. 2002. Tese (Doutorado em Psicologia)-Universidade Paris 13, Paris, 2002.

CHILAND, C. Homo psychanalyticus. Rio de Janeiro: Bertrand Brasil, 1993.

DELRIEU, A. Sigmund Freud: Index thématique. Paris: Anthropos, 1997.

FREUD, S. Alguns mecanismos neuróticos do ciúme na paranóia e no homossexualismo (1922). In: . Obras Psicológicas Completas de Sigmund Freud. Rio de Janeiro: Imago, 1976. v. XVIII, p. 267-281. Edição Standard Brasileira.

FREUD, S. Análise de uma fobia em um menino de cinco anos (1909). In:

Obras Psicológicas Completas de Sigmund Freud. Rio de Janeiro: Imago, 1976. v. X, p. 11-154. Edição Standard Brasileira.

FREUD, Sigmund. Análise terminável e interminável (1937). In: . Obras

Psicológicas Completas de Sigmund Freud. Rio de Janeiro: Imago, 1975. v. XXIII, p. 239-287. Edição Standard Brasileira.

FREUD, S. Atos obsessivos e práticas religiosas (1907). In: . Obras Psicológicas Completas de Sigmund Freud. Rio de Janeiro: Imago, 1976. v. IX, p. 117-131. Edição Standard Brasileira.

FREUD, S. Fantasias histéricas e sua relação com a bissexualidade (1908). In: . Obras Psicológicas Completas de Sigmund Freud. Rio de Janeiro: Imago, 1976. v. IX, p. 159-170. Edição Standard Brasileira.

FREUD, S. Fetichismo (1927). In: - Obras Psicológicas Completas de Sigmund Freud. Rio de Janeiro: Imago, 1974. v. XXI, p. 173-185. Edição Standard Brasileira.

FREUD, S. Inibições, sintomas e ansiedade (1925-1926). In: . Obras Psicológicas Completas de Sigmund Freud. Rio de Janeiro: Imago, 1976. v. XX, p. 93-201. Edição Standard Brasileira.

FREUD, S. Leonardo da Vinci e uma lembrança da sua infância (1910). In: . Obras Psicológicas Completas de Sigmund Freud. Rio de Janeiro: Imago, 1970. v. XI, p. 53-124. Edição Standard Brasileira. 
FREUD, S. Neurose e psicose 1924. In: . Obras Psicológicas Completas de Sigmund Freud. Rio de Janeiro: Imago, 1976. v. XIX, p. 185-193. Edição Standard Brasileira.

FREUD, S. O problema econômico do masoquismo (1924). In: . Obras Psicológicas Completas de Sigmund Freud. Rio de Janeiro: Imago, 1976. v. XIX, p. 195-212. Edição Standard Brasileira.

FREUD, S. Repressão (1915). In: - Obras Psicológicas Completas de Sigmund Freud. Rio de Janeiro: Imago, 1974. v. XIV, p. 163-182. Edição Standard Brasileira.

FREUD, S. Sobre o narcisismo: uma introdução (1914). In: Obras Psicológicas Completas de Sigmund Freud. Rio de Janeiro: Imago, 1974. v. XIV, p. 83-119. Edição Standard Brasileira.

FREUD, S. Uma neurose demoníaca do século XVII (1922-1923). In: Obras Psicológicas Completas de Sigmund Freud. Rio de Janeiro: Imago, 1976. v. XIX, p. 85-133. Edição Standard Brasileira.

FREUD, S. Analyse der phobie eines fünfjährigen Knaben (1909). In:

Studienausgabe. Frankfurt-am-Main: Fischer Verlag, 1969. Bd. VIII, S. 9-123. Zwei kinderneurosen.

FREUD, S. Analisis de la fobia de un niño de cinco años (Caso Juanito) (1909). Obras Completas. Madrid: Biblioteca Nueva, 1973. Tomo II, p. 1365-1440.

LACAN, J. Le Séminaire: la relation d'objet. Paris: Seuil, 1994. Livre IV

LACAN, J. Le Séminaire: les psychoses. Paris: Seuil, 1981. Livre III.

LACAN, J. Le Séminaire: encore. Paris: Seuil, 1975. Livre XX.

LACAN, J. "Propos sur l'hystérie". Conferência feita em 26 de fevereiro de 1977, em Bruxelas. Texto inédito, transcrito por J. Cornet e I. Gilson e reproduzido segundo a autorização de Jacques-Alain Miller, em Petits Écrits et Conférences (1945-1981). (Association Freudienne Internationale).

MITCHELL, J. Loucos e medusas: o resgate da histeria e do efeito das relações entre irmãos sobre a condição humana. Rio de Janeiro: Civilização Brasileira, 2006.

MITCHELL, J. Psicanálise da sexualidade feminina. Rio de Janeiro: Campus, 1988. 
Ricardo Lincoln Laranjeira Barrocas; Maria Luciana Silva Fernandes Félix

NASIO, J-D. A histeria: teoria e clínica. Rio de Janeiro: J. Zahar, 1991.

ROUDINESCO, E.; PLON, M. Dicionário de psicanálise. Rio de Janeiro: J. Zahar, 1998.

WINTER, J.-P. Les errants de la chair: études sur l'hystérie masculine. Paris: Calmann-Lévy, 1998.

Recebido em:junho de 2009

Aceito em:maio de 2010 